$\xi=-1{ }^{2}$

\title{
Jananee janmabhoomischa: ICT solutions for pronational digital society
}

\author{
N. Srihari Rao ${ }^{1 *}$, K. Chandra Sekharaiah ${ }^{2}$, A. Ananda Rao ${ }^{3}$ \\ ${ }^{1}$ Research Scholar, JNTUA University, Anantapuramu, Andhra Pradesh, India \\ ${ }^{2}$ School of Information Technology, JNTUH University, Hyderabad, Telangana, India \\ ${ }^{3}$ JNTUA College of Engineering, JNTUA University, Anantapuramu, Andhra Pradesh, India \\ *Corresponding author E-mail: raon2006@gmail.com
}

\begin{abstract}
Personality Development', 'Social Development', 'National Development', 'National Spirit', 'National Amity', 'Nation Building Character', 'National Consciousness', 'National Solidarity', 'National Awareness', 'National Integration', 'National Sovereignty', 'National Integrity', and 'National Unity' are the diminishing ideas among the citizens of a country now-a-days. Opportunities for cybercrimes worsen this situation further by luring the people with bad motivations, some who justify the cybercrimes somehow and some to perpetrate the cybercrimes. As the public authorities are not capable enough to handle cybercrime cases well as of now or due to lacunae in cyber laws, cyber criminals are evading and sweeping under the carpet. The societal status, may it be progressive or perishable depends on the kind of information that is provided to the people of society. If society is input with right information, the society will progress, develop positively and on the other hand the society will perish with the wrong or garbage information. In this context, Right-To-Information (RTI) Act 2005 plays a vital role by providing 'Right Information' through 'Information Transparency'. We found out an organization named JNTUHJAC (offline) with its website with URL- www.jntuhjac.com (online) running from so many years, committed three or more cybercrimes against the Union of India. We considered this online and offline organization for our case study and for discussions of our solutions for these cybercrimes. In this paper, we proposed a research methodology based on Information and Communication Technology (ICT) approaches to prevent the conversion of Cybercrime or Ill-Informed Society into Perishable Society and hence hope to succeed in transforming Cybercrime or Ill-Informed Society into Well-Informed Society and hence into a "Progressive Society/Knowledge Society/Digital Society.
\end{abstract}

Keywords: Jawaharlal Nehru Technological University Joint Action Committee (JNTUHJAC); Government-of-Telangana (GoT); State Emblem of India (Prohibition of Improper Use) Act 2005 (SEIPIUA); Fake Government-of-Telangana (FGoT); Cheating Government-of-Telangana (CGoT); Seditious Government-of-Telangana (SGoT); Got Whose Appointed Day Is 2Jun 2014 After the Parliament Passed the A.P. Reorganization Bill (PGoT); Cybercrime, Information and Communication Technologies (ICTS), Public Information Authority (PIO); Right-to-Information (RTI) Act 2005.

\section{Introduction}

Today we hear lot of news in many different Television (TV) media, watch many stories in movie media, read many essays and incident stories in print media on a variety of cybercrimes and their consequences. Cybercrimes are unwanted and destructive actions that may affect one or more individuals, institutes, organizations, even states or nations. Dealing with cybercrimes is not as easy as it is discussed about, but requires multi skills and persistent efforts to detect and defuse its effects on an individual, society, or nation. It is known by many news websites that many cybercrimes are being reported by victims in concerned departments where they expect to get solutions, but no action is being taken to provide quick solutions to the victims or no convictions and punishments imposed against the cybercriminals who committed them.

Right information is the information which is correct or accurate and communicated well to the people who need it. We describe a 'Well Informed Society' as a society that is nurtured with 'Right Information'. In a Knowledge Society, the government has transparency in its operations and exhibits vital statistics about the economy, plans for future and current social and economic indicators in such a manner that it can be easily accessed by all sections of the society. In a digital society, Information and Communication Technologies (ICTs) are adopted and integrated at home, workplace, education and recreation fields. 'Wrong Information' or 'Garbage Information' is the information which is worthless, useless, and rubbish or not correctly communicated or not at all communicated to the people who need right information. We describe 'Ill-Informed Society/Cybercrime Society' as a society that is nurtured with 'Wrong or Garbage Information' and hence is prone to perish.

\section{a) Motivation}

The author found out two organizations an offline organization i.e. JNTUHJAC that has been prevalent in JNTUH environment and its online website with URL - www.jntuhjac.com during 'Telangana agitation' from the year 2011, to have committed multiple cybercrimes. Hence, we have taken up a cybercrime case study about these two cybercriminal organizations which have committed multiple cybercrimes against the Union of India namely State Emblem of India (Prohibition of Improper Use) Act 2005 (SEIPIUA) violation, Fake Government-of-Telangana (FGoT), Cheating Government-of-Telangana (CGoT), and Seditious Government-of-Telangana (SGoT) crimes [6]. It is evident from the automated web crawl image of the homepage of www.jntuhjac.com dated 12 November 2011 as given in Fig. 1 [5]. 


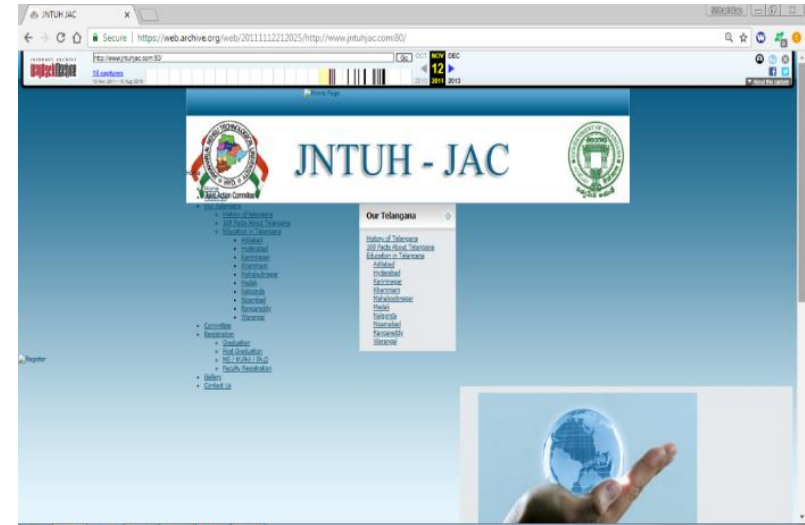

Fig. 1: Screenshot of Homepage of www.Jntuhjac.com Website as on 12 November 2011.

The homepage shown here contains an image with a logo on the R.H.S. which contains 'Indian National Emblem' comes under SEIPIUA violation cybercrime [2]. We also find mention of 'Government of Telangana' in the logo on the R.H.S. This is not only CGoT cybercrime but also SGoT cybercrime. This FGoT is misleading and cheating the nation [4]. The logo is part of the image during the years 2011 to 2014. As per the recent content on the homepage of www.jntuhjac.com website, nearly 201400 registrations are done in which UG (1462), PG (358), M.S. /M.Phil. /Ph.D. (106), Teaching and Non-Teaching Faculty (88) of the JNTUH University are registrants. It is a big data crime with the degree of crime being nearly $16,112(=2 \times 2014 \times 4)$ and the Table 1 shows the brief figurative details of cybercrimes related to our case study and illustrates the measure of 'degree of cybercrime' [24].

Table 1: Illustration of Degree of Crime

\begin{tabular}{lll}
\hline $\begin{array}{l}\text { No of Cyber Crimi- } \\
\text { nal Organizations }\end{array}$ & $\begin{array}{l}\text { No of Reg- } \\
\text { istrations }\end{array}$ & No of Crimes \\
\hline $\begin{array}{l}\text { 2 (JNTUH JAC and } \\
\text { CSGoT) }\end{array}$ & $\begin{array}{l}\text { 2014 ap- } \\
\text { proximately }\end{array}$ & $\begin{array}{l}\text { 4 (Cheating, Identity Theft, Se- } \\
\text { dition, State Emblem Improper } \\
\text { Use) }\end{array}$ \\
\hline
\end{tabular}

In spite of relentless efforts made by the author through the complaints to JNTUH V.C. and the SHO of KPHB P.S. to take proper action to nullify the cyber criminal activities in JNTUH academic environment as indicated in [8, 20], JNTUH University academic administrators as well as SHO of KPHB P.S. did not take any action to discourage the role of JNTUHJAC organization which is off line and its website www.jntuhjac.com online. The JNTUH University academic administrators failed to preserve the normal relationships among university stakeholders and stakeholders did not show compliance to the regular academic environment. The response from the management of JNTUH University and the KPHB P.S. police authorities gave an outlook and appearance to us that the management of JNTUH University and the above mentioned police authorities shook hands with the separatists with cyber criminal agenda and encouraged the separatists' activities which perpetrate sedition like crimes.

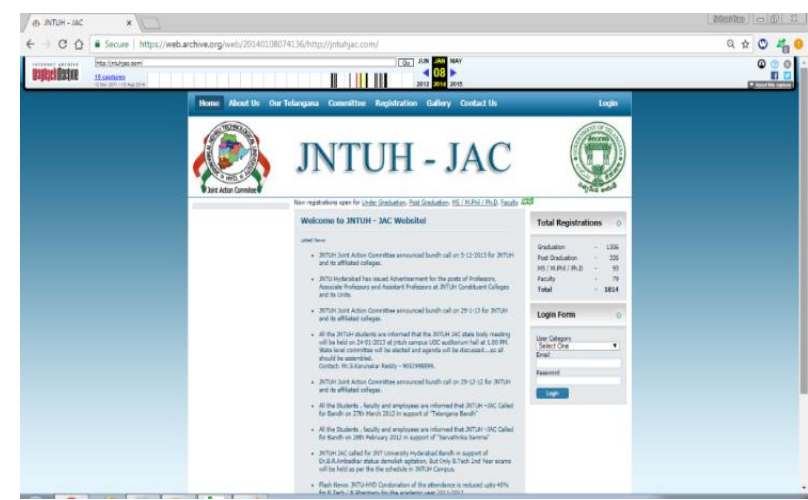

Fig. 2: Screenshot of Homepage of www.jntuhjac.com Website as on 8 January 2014.

Recently, this online organization has modified the web pages of its website and the web pages now do not contain State Emblem of India, and the mention of 'Government of Telangana' which were included in the homepage in the past. It indicates the difficulty in identification of cybercrimes because of volatile nature of such witness instruments in cyber space and great complexity involved in handling these kinds of cybercrimes. To trace the cybercrime correctly, we had taken the task of mining the web through the Wayback machine, a web crawler tool for Internet archiving of websites. Through web crawling, we found that the JNTUHJAC organization with its website www.jntuhjac.com has as many as three years of cyber criminal background as is evident from the screenshots obtained using the web crawler tool on Wayback machine on dates 12Nov 2011, and 8Jan2014 as given in Fig. 1 \& 2. In this context, we performed our research to find out the solutions for the above mentioned cybercrime problems.

b) Jananee Janmabhoomischa

We attribute our motivation to take up our research on cybercrimes in this direction to the phrase "Janani Janmabhoomischa Swargadapi Gareeyasi". The phrase "Janani Janmabhoomischa Swargadapi Gareeyasi" comes from Yuddha Kanda of Valmiki Ramayana. The full Shloka is:

"Api swarnmayi Lanka na me Laxman rochate|

janani janmabhumishcha swrgadapi gariyasi \|"

The meaning of this Shloka is: This golden Lanka does not fascinate me, as mother and motherland are superior to heaven. This was said by Lord Rama to his brother Lord Lakshmana on entering Lanka after slaying King Ravana in battle. Nepal country uses the phrase "Janani Janmabhoomischa Swargadapi Gareeyasi" as their motto on their National Emblem. According to this shloka, we see the need to respect our mother and motherland (birthplace) more than heaven.

Our paper is organized as follows. Section II describes the literature survey conducted to appreciate the cybercrime problems and proposed solutions. Section III presents our proposed research methodology intended for transforming a Cybercrime Society to a Progressive Society using a case study. Section 4 concludes the paper with the mention of some future directions.

\section{Related work}

We carried out the literature review related to our research work and the details are presented as follows. The first groundwork related to the cybercrimes involved in the continuing case study was present in [1]. From the elaboration of the work w.r.t. the issues, the issues and details were presented on better grounds in [2]. The research work gained strong ground as in [3-7], [18], as the cyberforensic evidence of the cybercrimes was thoroughly captured and presented on more elaboration of reporting and recording the details. The work in $[4,10]$ depicts the impact of RTI Act to challenge the conditions that were against the pursuing for the field reporting and ensuring the registration of the cybercrime to successfully persuade the public authorities for right information in the IT era we are in.

The research work in [9], [16 - 26], [28] focuses attention on a cyber remedial forum against the cybercrimes case study to campaign and spread awareness about the twin cybercriminal organizations JNTUHJAC and the CSGoT in order to garner the public strength and regain the national losses owing to the impact of the cybercrimes in the case study. In [11], [12], [22], nearly 50 interrogation-like, information-retrieving points and issues raised and laid under an RTI application are presented together with the investigation and prosecution details of the cybercrime. The impact is to depict the maladaptive management in the organizational setting in the academic scenario under consideration and to advance adaptive management.

The charge sheet of the first cybercrime registered as regards the case study is analyzed in [13] to evaluate the search for the right 
information and how a cybercrime issue is tracked and handled in the information technology era during the course of investigation. In $[14,15]$, multiple attributes of the judgement related to the cybercrime handled otherwise as a normal one as violation of State Emblem of India (Prevention of Improper Use) Act 2005 are presented to show how a cybercriminal case is mishandled by the law enforcement agencies w.r.t. the investigation, w.r.t. the lacunae in the handling of the cybercrime lifecycle in the multiple cybercrimes case study.

\section{Research methodology}

Initially, we present the important terminology that is used in our proposed research methodology.

a) Principle of Information Transparency

Information Transparency is defined as the presentation of information so that it is openly available, accessible, comprehensive and clearly understandable to the ones who needs it. There are different ways in which the organizational information can be kept transparent to the public by the public authorities. Information can be released in the form of booklets, yearly /half yearly /quarterly /bimonthly /monthly /weekly (physically), served digitally by soft copies (virtually), can be displayed on the websites (online), and set up separate information departments in the organizational premises to serve both online and offline. Information Transparency is the goal of ICTs as evident in [10].

b) Importance of RTI (Right-To-Information) to Common Citizens

The common citizens put their trust in the system hoping them to work efficiently, fairly and impartially. But due to the increased evil of corruption in all departments of states and nation, transparency in the information/system is forbidden and forgotten. Prior to the RTI Act 2005, the public authorities were so careless about common people and generally they were hiding information from the public and were very reluctant to provide right services to these common people. It all happened because there is no accountability explicitly imposed on these public authorities. This limitation is deemed to be overcome with the advent of RTI Act in 2005. Right information is the goal of Right-To-Information (RTI) Act. It is a weapon against erring authorities. This is clearly evident in the solution part of [8], [10], [21] to the cybercrime under case study where the RTI Act enabled registering the F.I.R. against the unregistered organized group JNTUH-JAC in JNTUH premises. Information Transparency as defined above provides this excellent opportunity to the common men.

c) Well-Informed Society

An Informed Society (i.e. Well-Informed Society) is defined as a society where citizens have the resources, education and skills to access and participate in the free flow of reliable and pertinent information through a diverse range of platforms and media organizations that empower them to make considered decisions about their economic, social and political lives. That is "Information is Liberating". RTI is a powerful tool to every citizen of a country that strengthens the democracy and promotes good governance by increasing people's participation. Using RTI, anyone can ask any question to the concerned officials about any government project or work. The public authorities are deemed to provide right information to the information users in the society which ensures the society to be a Well-Informed Society. RTI Act is utilized to gather right information, and hence resulted in remedial actions against the cybercrimes as in [8], [10], [20].

d) Knowledge Society

A Well-Informed Society is a Knowledge Society or a Progressive Society. Knowledge is fundamental to politics, economics, and culture of modern society. For example knowledge economy is created by economists and the learning society is created by educators. Knowledge is a valuable commodity than can be traded for economic growth. A Knowledge Society generates, shares, and makes available to all members of the society knowledge that may be used to improve the human condition. We know "Knowledge is Power".
Our goal is to have a Knowledge Society. In relation with the cybercrime case study, the author has published a plenty number of research papers which provide knowledge for the students, researcher scholars, and citizens which enabled the society to become a Knowledge Society [1-26].

e) Digital Society

A Digital Society can be defined as a society which is progressive and knowledge based that is formed as a result of the adoption and integration of Information and Communication Technologies (ICTs) at home, work, education, recreation, and allied fields. People make use of various government services, pay their bills and taxes, access important information and register companies through an online gateway that works $24 / 7$ in a digital society. People give priority to reliable and secure electronic transactions to cash. All residents are issued national identity cards based on smart-card technology that enables biometric authentication with a capability for multiple-applications such as personal identification, medical records, employment status and financial transactions all in a single card. The usage of ICTs as the solution to the ICT problems as in [3-5], [10] inspires ICT users further to adapt ICT capabilities to counter cybercrime problems.

\section{f) Road-to-Information-Technology (RIT) is RTI}

The Information Technology (IT) is generally expected to be working as a solution for a variety of tasks now-a-days. That is why millions and millions of websites are set up and made ready for providing transactional or non-transactional web services online. Having a plenty number of public organizational websites on the Internet does not mean that all these web services are appropriately functioning and delivering services to common citizen users. This is evident from our extensive observations that the websites which are set up as an essential online services do not function as they are deemed to do but they simply struck up without any intended outcomes to the user community. With only Information Technology and without RTI, the base for solutions is just a damaged one. Nevertheless, RTI Act 2005 can be used to work as a roadmap to make use of IT in our lives. In this regard, we believe RTI will be an excellent solution. RTI becomes a powerful tool to bring awareness to the nationals about nation's cyber space, its status and trigger the reaction to the nonfunctional IT sections and services that are deemed otherwise to function. The cumulative force from the citizens who are inspired to react to these circumstances can be deemed to bring about very desirable outcomes and that helps in obtaining a correctly functioning IT sections and services. The RTI rings its bells when there is a mismatch of actual and expected Information Technology service conditions. As in [8 - 10], [20], [21], [24 - 26] IT can be used in the light of RTI in order to defuse the deleterious effects of cybercrimes. We made use of relevant web pages (P-Governance Forum) [28], and very popular social networking sites such as facebook, twitter, etc. to bring good awareness and feed smart solutions (ICT solutions) to the society to combat cybercrimes in our case study. Hence, RTI Act 2005 will assist as a "Road to Information Technology".

g) National Life

National Life means living a life that shows one's belongingness to the nation, 'love and devotion to motherland', and strong sense of alliance with other citizens who share the same values. The citizens with national life have respect for the nation and for the laws of the land, follow the footsteps of great national personalities like Mahathma Gandhi, and Netaji etc. These people will inculcate national spirit in the children, and strive for the enhancement of the national fabric. Building national life for all citizens will be the focus of work for people leading the national life. JNTUH regular academic environment was polluted with cybercriminal organizations $[9,18$, 22] which brought in us the feeling that the JNTUH authorities have criminal regionalism and hence did not have positive 'National Life' and similarly with the KPHB P.S. police authorities. In other words, JNTUH authorities and KPHB P.S. police authorities are missing nation building character as they did not have positive ' $\mathrm{Na}$ tional Life'.

h) Quality of Life (QoL) 
It is the general well-being of a person, family, society, or community defined in terms of comfort, satisfaction, health, and happiness rather than wealth. Positive QoL indicates the progress in society over a period of time whereas negative QoL indicates the degenerated society over a period of time. Citizens of a country should have positive QoL. There are many attributes/parameters that indicate the QoL of a person/family/society/community are given in the Table 2. We found that the positive QoL with the members of PGF [28], was able to show good paths to a cybercrime-free society and cybercrime-free nation at large.

i) Quality of National Life (QoNL)

Quality of National Life can be defined as a general well-being of a nation defined in terms of development, amity, sovereignty, unity, integrity, solidarity, and national consciousness rather than nation's wealth. Positive QoNL indicates the progress in nation over a period of time whereas negative QoNL indicates the degenerated nation over a period of time. Citizens of a country should have positive QoNL. There are many attributes/parameters that indicate the QoNL of a nation are given in the Table 2. If the QoNL possesses high values for the positive attributes and low values for the negative attributes, then we have the most desirable treatment against the cybercrimes that may occur in the nation. This way we can see that we achieve the prevention or at least proper/perfect mitigation of cybercrimes that occur against our national spirit.

It is evident from our review of the sequence of incidents mentioned in [1-26] w.r.t. our cybercrime case, we got to understand that people without positive QoNL cannot impart QoL at national level to any other citizen of the nation. Such people fail to acquire and adopt the most essential element, 'National Spirit' that is the root of 'National Development'. We liked to deal with the cybercrime incidents in the presence of positive QoNL people together with the research methodology that is described in the later sections of this paper.

\section{j) Force of Positive elements}

The force of negative elements is comparatively higher than the force of positive elements. Hence in order to counteract the impact of very few negative elements, we shall opt for a substantial number of positive elements. With the criminal motivation of offline organization i.e. JNTUH JAC as many as 2014 registrations were done in the associated online cybercriminal organization i.e. www.jntuhjac.com [16], [17]. In this case study, as a solution, we like to opt for a variety of ICT solutions to counteract the force of negative elements (here, cybercrimes). We developed guidance and counseling web pages [28], set up specialized content on fighting cybercrimes in social networking websites [29], [30] that helps the victims or potential victims to get rid of cybercrime problems.

k) Vicious Society to Virtuous Society

A society may become a Vicious Society from a series of destructive events that create a Vicious Circle. At this point the society is completely polluted and it is now no longer possible to repair. ICT is useful to the development of society at the same time with only ICT, facilitates people to become cybercriminals luring them in one way or the other. Hence, ICT alone may not be a standalone solution to the problems and hazards occurring due to Vicious Society. A Virtuous Society is a society in which there are people who are proactive and pronational who help other people or society from coming out of vicious circles and bring them out of deleterious conditions and prepares others similar to them. A Virtuous Society [28 30], will easily progress and show paths to nation's progress.

1) Pronational Workforce

Antinational means people who are opposed to national interests or nationalism. Antinational workforce $[1,2]$ is a team of people who are engaged in doing things that harm the nation.

Table 2: Comparison of Attributes of Quality of Life with Attributes of Quality of National Life

\begin{tabular}{llll}
\hline $\begin{array}{l}\text { s. } \\
\text { no }\end{array}$ & $\begin{array}{l}\text { attribute / } \\
\text { parameter }\end{array}$ & $\begin{array}{l}\text { nature of quality of } \\
\text { life (qol) }\end{array}$ & $\begin{array}{l}\text { nature of quality of } \\
\text { national life (qonl) }\end{array}$ \\
\hline \multirow{2}{*}{ Abilities } & $\begin{array}{l}\text { Describes abilities at } \\
\text { personal, family, so- } \\
\text { cial and community }\end{array}$ & $\begin{array}{l}\text { Describes abilities of } \\
\text { a person's or society }\end{array}$ \\
\hline
\end{tabular}

\begin{tabular}{|c|c|c|c|}
\hline & & $\begin{array}{l}\text { levels. Examples are } \\
\text { employability, busi- } \\
\text { ness, and entrepreneur } \\
\text { skills etc. }\end{array}$ & $\begin{array}{l}\text { at national level. Ex- } \\
\text { amples are national } \\
\text { leadership, profes- } \\
\text { sional and research } \\
\text { capabilities. }\end{array}$ \\
\hline 2 & $\begin{array}{l}\text { Belonging- } \\
\text { ness }\end{array}$ & $\begin{array}{l}\text { Describes belonging- } \\
\text { ness at personal, fam- } \\
\text { ily, social, and com- } \\
\text { munity levels. }\end{array}$ & $\begin{array}{l}\text { National Belonging- } \\
\text { ness }\end{array}$ \\
\hline 3 & Diversity & $\begin{array}{l}\text { Regional, caste, reli- } \\
\text { gious diversities }\end{array}$ & $\begin{array}{l}\text { Cultural, traditional, } \\
\text { linguistic, geo diversi- } \\
\text { ties }\end{array}$ \\
\hline 4 & $\begin{array}{l}\text { Demands } \\
\text { and Respon- } \\
\text { sibilities }\end{array}$ & $\begin{array}{l}\text { Personal, Family, So- } \\
\text { cietal and community } \\
\text { demands and responsi- } \\
\text { bilities }\end{array}$ & $\begin{array}{l}\text { National demands and } \\
\text { responsibilities. }\end{array}$ \\
\hline 5 & Expectations & $\begin{array}{l}\text { Personal, family, so- } \\
\text { cial, community ex- } \\
\text { pectations }\end{array}$ & $\begin{array}{l}\text { National expectations. } \\
\text { Example is Prime } \\
\text { Minister should be a } \\
\text { dynamic and excel- } \\
\text { lently serving person. }\end{array}$ \\
\hline 6 & Freedom & $\begin{array}{l}\text { Personal, family, so- } \\
\text { cial, community free- } \\
\text { dom }\end{array}$ & $\begin{array}{l}\text { Freedom at country } \\
\text { level }\end{array}$ \\
\hline 7 & Happiness & $\begin{array}{l}\text { Personal, family, so- } \\
\text { cial, community hap- } \\
\text { piness }\end{array}$ & $\begin{array}{l}\text { National happiness } \\
\text { which means happi- } \\
\text { ness for all citizens of } \\
\text { the nation. }\end{array}$ \\
\hline 8 & Identity & $\begin{array}{l}\text { Identity at personal, } \\
\text { family, social, com- } \\
\text { munity levels. }\end{array}$ & $\begin{array}{l}\text { Identity at national } \\
\text { level }\end{array}$ \\
\hline 9 & $\begin{array}{l}\text { Improve- } \\
\text { ment }\end{array}$ & $\begin{array}{l}\text { Improvement at per- } \\
\text { sonal, family, social, } \\
\text { community levels. }\end{array}$ & $\begin{array}{l}\text { Improvement at na- } \\
\text { tional level }\end{array}$ \\
\hline 10 & Knowledge & $\begin{array}{l}\text { Knowledge at per- } \\
\text { sonal, family, social, } \\
\text { community levels. }\end{array}$ & $\begin{array}{l}\text { Knowledge at national } \\
\text { level }\end{array}$ \\
\hline 11 & $\begin{array}{l}\text { Opportuni- } \\
\text { ties }\end{array}$ & $\begin{array}{l}\text { Opportunities at per- } \\
\text { sonal, family, social, } \\
\text { community levels. }\end{array}$ & $\begin{array}{l}\text { Opportunities at na- } \\
\text { tional level }\end{array}$ \\
\hline 12 & Possibilities & $\begin{array}{l}\text { Possibilities at per- } \\
\text { sonal, family, social, } \\
\text { community levels. }\end{array}$ & $\begin{array}{l}\text { Possibilities at na- } \\
\text { tional level }\end{array}$ \\
\hline 13 & Religion & $\begin{array}{l}\text { Religion at personal, } \\
\text { family, social, com- } \\
\text { munity levels }\end{array}$ & $\begin{array}{l}\text { Religion at national } \\
\text { level }\end{array}$ \\
\hline 14 & Satisfaction & $\begin{array}{l}\text { Satisfaction at per- } \\
\text { sonal, family, social, } \\
\text { community levels. }\end{array}$ & $\begin{array}{l}\text { Satisfaction at na- } \\
\text { tional level }\end{array}$ \\
\hline 15 & Security & $\begin{array}{l}\text { Security at personal, } \\
\text { family, social, com- } \\
\text { munity levels. }\end{array}$ & $\begin{array}{l}\text { Security at national } \\
\text { level }\end{array}$ \\
\hline 16 & Well-being & $\begin{array}{l}\text { Personal, family, so- } \\
\text { cial, community well- } \\
\text { being }\end{array}$ & National well-being \\
\hline 17 & $\begin{array}{l}\text { Working } \\
\text { Conditions }\end{array}$ & $\begin{array}{l}\text { Working conditions at } \\
\text { personal, family, so- } \\
\text { cial, community lev- } \\
\text { els. }\end{array}$ & $\begin{array}{l}\text { Working conditions at } \\
\text { national level }\end{array}$ \\
\hline
\end{tabular}

For example, naxalites, and terrorists, whose motives and activities are against the government and government departments. Pronational means people who are patriots and fight for the country they belong to in the interest of nation. Pronational Workforce is a team of people who work for the nation they belong to, have commitment for 'National Development', 'National Sovereignty', 'National Unity', 'National Amity', 'Nationa Integration' and the like. Pronational workforce is the need of the hour as the cybercrimes are increasing rapidly now-a-days that create Vicious Society. India needs 'Pronational Workforce' which can relentlessly fight with the devastating cybercrimes that may occur at any time.

m) Social Networking Sites (SNSs)

Social networking sites are powerful tools to bring about a public opinion, political, or other minor/major changes in the society. We created facebook, twitter and few more social accounts for bringing the awareness among the stakeholders of ICT about our cybercrime case study. In addition we made use of the SNS sites to guide and 
counsel the computer educated/ICT conscious people $[29,30]$ in order to trigger response from these sections of the nation.

n) Methodology

Cyber criminals may abuse any kind of opportunity found over time as a facility and timing to conduct and commission cybercrimes. The cybercriminals choose victims in the society to the cybercrimes and endanger societies and convert the societies into Cybercrime Societies. The societies can become Well-Informed societies or IllInformed Societies based upon the type of information given to the people of society who need it. The Wrong Information or the Garbage Information that is given to the people of society will convert that society to Ill-Informed Society as shown in Fig. 3. It may not be the case for all Ill-Informed Societies to be Cybercrime Societies. It is because certain Wrong Information/Garbage Information given to the people of society need not do harm to the society. But, when the society becomes Cybercrime Society, it may be pressed to become a Perishable Society. On the other hand if Right Information is fed to people of society who need it, the society will be a Well-Informed Society and hence can become a Progressive/Knowledge/Digital Society as shown in Fig. 4.

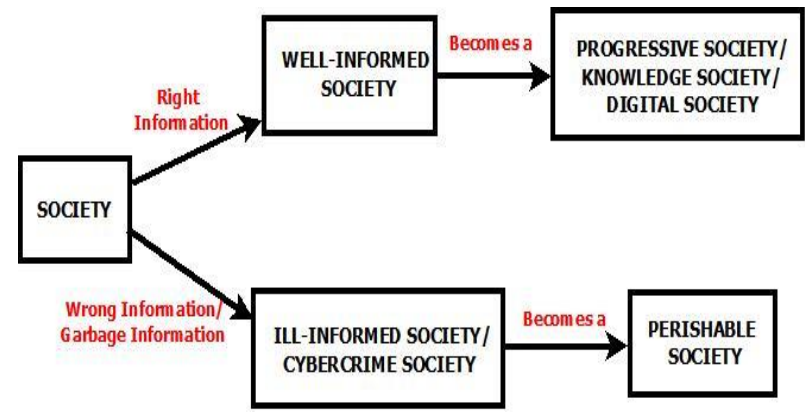

Fig. 3: Well-Informed Society Contrasted with Ill-Informed Society.

The online organization www.jntuhjac.com contained fake and false information and hence needed to be considered as cybercriminal organization because it turned the society to a cybercriminal society by making members of JNTUH academic society as members of the above online cybercriminal organization. When such Cybercriminal Information/Wrong Information/Garbage Information propagated in the JNTUH academic environment, it could pollute gradually the larger environment that were in line, hence preparing an Ill-Informed Society/Cybercriminal Society which, in worse conditions leads to a Perishable Society.

When the author gave complaints to the JNTUH V.C. and the SHO of KPHB Police Station with regard to the cybercrimes committed by both offline JNTUHJAC organization and its online counterpart www.jntuhjac.com, neither JNTUH V.C. nor SHO of KPHB P.S has taken any action. Afterwards the author has put an RTI application highlighting the cybercrime case and put lot of efforts to take proper action against the above two cybercriminal organizations, in order to nullify effects of these cyber criminal activities in JNTUH academic environment. But, he did not succeed because the JNTUH university authorities responded with misleading information only. When certain information is requested for knowing the state-of-affairs in the JNTUH academic environment from Public Information Authority (PIO) of JNTUH, "a premier technology institute in India", the author did not get information as a response at par with the actual circumstances. The Wrong Information fed by some public authority can mislead the people of society and make up the Cybercrime Society as it happened in [10]. The cybercrime society if left not dealt with any research methodology will make that society a Perishable Society.

In our research work we proposed a research methodology that can counter the conversion of Cybercrime Society into a Perishable Society, instead to transform that society to a Progressive Society by Pronational Workforce as shown in Fig. 4. Information Transparency is a good solution for transforming a Cybercrime Society into a Well-Informed Society and hence it can be utilized as an instru- ment for the positive good to the nation. We implement this research methodology using Information and Communication Technologies (ICTs) with regard to achieving information transparency to all the people of society. By utilizing Information and Communication Technologies (ICT) we set up enough web pages titled " $\mathrm{P}$ Governance Forum (PGF)" [28] to bring awareness against cybercrimes among people of society and pass information on the stateof-affairs regarding relevant cyber crimes that occur currently/occurred in the past. RTI Act that acts as a 'Road to IT' can pave a trusted path to transform the Cybercrime Society to a Well-Informed Society. The author has published as many as 24 research papers related to this cybercrime case under study which relates several disciplines of study such as psychology, national citizen's behavior, law-enforcement-related, academics etc. points of view all for the national interests. The desired outcomes from the methodology can be obtained, provided if a Pronational Workforce, which sets correct path to lead the society to a Progressive Society/Knowledge Society/Digital Society is built.

As the positive forces gathered, and developed in alliance with the national spirit [3-26, 28] a team with name 'Pronational Workforce' was conceived and started its activities to do away the antinational workforce activities. The author continued his efforts with the Pronational Workforce, appealed to the higher PIO authorities at which time the higher PIO authorities passed some orders, given some decision notices to their subordinate PIO authorities to take necessary actions. Hence the concerned PIO, SHO of KPHB P.S. registered F.I.R related to one cybercrime namely SEIPIUA violation and conducted investigation. This led to filing a charge sheet against the accused A1. In the charge sheet, it was mentioned that among the two accused, accused A1 had committed his crime, and accused A2 was in absconding state. In the court trial, accused A1 was acquitted under benefit of doubt. It is the failure of police authorities to record the evidence during the enquiry process and examination of witnesses (2 Panches). The two Panch witnesses unfortunately became hostile witnesses [27], which prevented to take proper action against the accused persons.

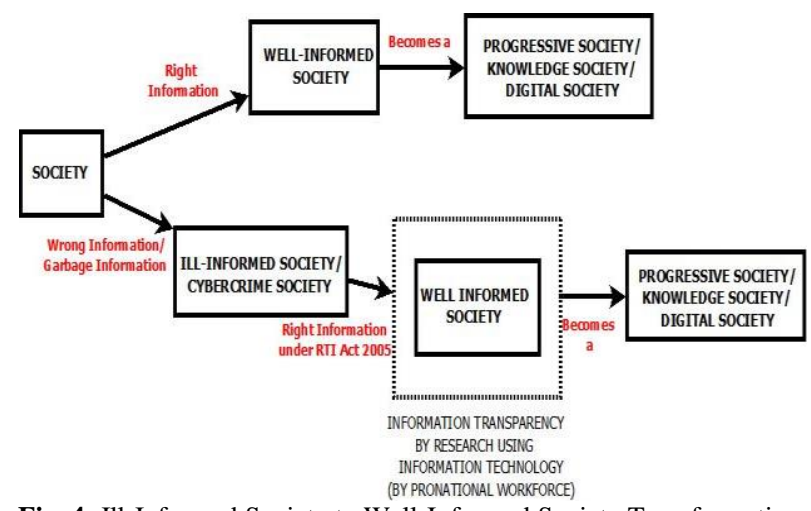

Fig. 4: Ill-Informed Society to Well-Informed Society Transformation.

Had the police authorities recorded the evidence from the Panch witnesses, the status should not have been like this. Had the Universities responded promptly with proper mechanism, this type of situation should not have happened. Since this type of condition occurred, we have taken the task of building smart citizens especially in JNTUH academic environment. This effort can be extended to large scale solutions by using RTI as a road to ICT as shown in Fig. 5. 


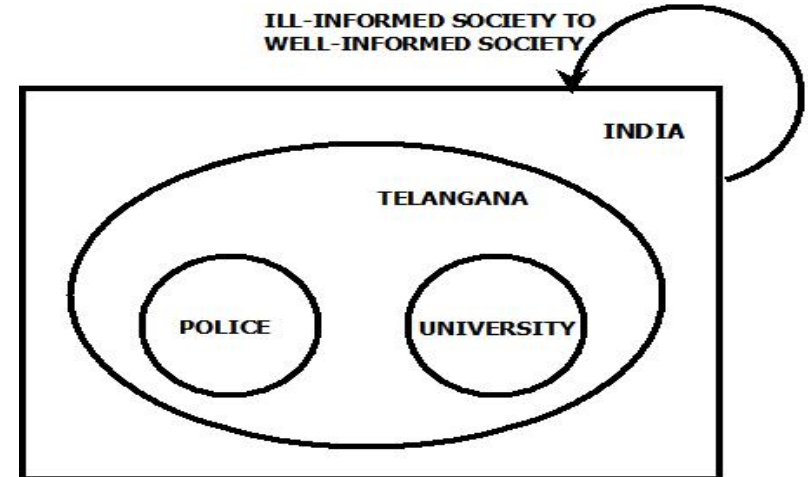

Fig. 5: Ill-Informed India to Well-Informed India Transformation in the context of Telangana.

o) Correlating 'JANANEE JANMABHOOMISCHA', 'Quality of National Life', and 'RTI Act 2005' for a 'Digital Society' In our proposed research methodology we took up the task of remedying the cybercrimes that occurred against our Union of India and a set of remedies are undertaken to mitigate the effect of these cybercrimes. As part of this task, the author has set up a webpage [26] that is meant to guide and counsel the JNTUH students of UG/PG/M.S./M.Phil./Ph.D., teaching and non-teaching faculty and obtain theirs and public opinion who are vulnerable to the cybercrimes mentioned above. The idea 'Janani Janmabhoomischa Swargadapi Gareeyasi' and 'life of positive QoNL' combined with 'RTI Act which is Road to IT' will be very much useful to bring out all necessary changes in the society and transform the Ill-Informed society/cybercrime society to a Well-Informed society there by preparing a strong "Progressive Society/Knowledge Society/Digital Society" as depicted in Fig. 6.

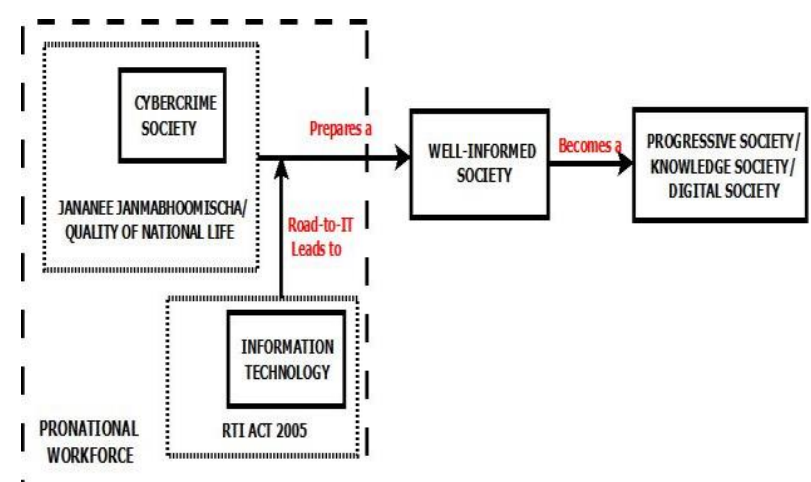

1. - - - - - -

Fig. 6: National Spirit embodied in 'Jananee Janmabhoomischa', 'Positive QoNL', and 'Road-to-Information Technology' Leads to A Strong 'Digital Society'.

\section{Conclusions and future scope}

A well informed society is a progressive society. Every citizen whether 'Ruling' or 'Ruled' must introspect oneself whether he is leading his life adhering to the eye-opening, great phrase "Janani Janmabhoomischa Swargadapi Gareeyasi" and check oneself that one is not a cyber criminal or an accomplice or a supporter to cyber criminals. Modern ICT usage should not lead people to take national life with levity. We try to impress on people of our nation that "Mother and Motherland are superior to Heaven" and to work for personality development, social development, and national development by imbibing these values in their lives. The cybercrime researchers need awareness and knowledge on how to prevent cybercrimes from occurring in the first place (a strong and most desirable solution), how to detect cybercrime incidents and identify the possible causes for specific cybercrimes (in the case of occurrence of cybercrimes), and how to respond to the cybercrime incidents (in the case of pursuit of cyber solutions to cybercrimes). The common people should be made aware of the general concepts and enough knowledge of cybercrimes. We proposed a research methodology that is based on information transparency and the use of ICT technologies for the positive good to the nation. Our guideline to the 'Government of Telangana' and 'Government of India' is to take necessary action against the two criminal organized outfits, both offline i.e. JNTUH-JAC and online www.jntuhjac.com organizations so that a regular academic environment in JNTUH University is retained and attract all online organizational websites to be cybercrime-free websites and help to build national spirit in the minds and lives of Indian citizens. The future work is, to keep our ultimate goal of our research, and it is to bring such awareness at large scale, provide guidance and counseling regarding cybercrimes, demonstrate to utilize ICT technologies in a meaningful way to be free from cybercrimes, and motivate them not to involve in any of cyber criminal activities.

\section{References}

[1] Usha Gayatri P., and Chandra Sekharaiah K., "Encasing the Baneful Side of Internet", National Conference on Computer Science \& Security (COCSS 2013), 5-6 April 2013, Sardar Vallabhbhai Patel Institute of Technology, Vasad, Gujarat, India.

[2] Usha Gayatri P., Neeraja S., Leela Poornima Ch., Chandra Sekharaiah K. and Yuvaraj M., "Exploring Cyber Intelligence Alternatives for Countering Cyber Crime", Proceedings of the 8th INDIACom; INDIACom-2014, International Conference on "Computing for Sustainable Global Development”, Mar.2014, Bharatiya Vidyapeeth's Institute of Computer Applications and Management (BVICAM), New Delhi, India.

[3] P. Usha Gayatri, K.Chandra Sekharaiah, D.Radhika, G.Sruthi, K Satish, S.Mounika, K.Shravani, Ambuja Kulshreshtha, "Exploring Cyber Intelligence Alternatives for Countering Cyber Crime:A Continuing Case Study for the Nation", in Proceedings of the IEEE CSI2015 Intnl. Conf.@Bharati Vidyapeeth's Institute of Computer Applications and Management (BVICAM), New Delhi, (INDIA), Dec. 2015 (Presented)

[4] P.Usha Gayatri , B.Tirupathi Kumar, K.Chandra Sekharaiah, "Exploring Cyber Intelligence Alternatives for Countering Cyber Crime: A Continuing Case Study for the Nation", Presented in 1st Intnl. Conf. on Advancements and Innovations in Engineering, Technology, \& Management(ICAIETM2017)@JBREC, Hyderabad \& published in International Journal of Innovations \& Advancement in Computer Science(IJIACS) ISSN 2347 - 8616 Volume 6, Issue 12 Dec2017, pp.394-397.

[5] B. Tirupathi Kumar, K Chandra Sekharaiah, P Mounitha, "A Case Study Of Web Content Mining In Handling Cybercrime”, In Proceedings of 2nd International Conference on Science, Technology and Management, 27Sep2015, Delhi University, New Delhi, pp.2290 2293, 971-81-931039-6-8 \& International Journal of Advance Research in Science and Engineering, Vol. No.4,Special Issue(01),Sep 2015, ISSN 2319-8354,pp 665-668

[6] P.Usha Gayatri and K.Chandra Sekharaiah, "A Case Study of Multiple Cybercrimes against the Union of India", International Journal of Computer \& Mathematical Sciences IJCMS ISSN 2347 - 8527 Volume 6, Issue 3 March 2017, pp.71-79, presented in NCIST2017@Manipur Institute of Technology, Manipur University, Imphal, India.

[7] P.Punitha, S. Vidyavathi, K.Chandra Sekharaiah, "Spatial Cognition Applications towards Swachch Digital India", Presented in 1st Intnl. Conf. on Advancements and Innovations in Engineering, Technology, \& Management(ICAIETM2017)@JBREC, Hyderabad \& published in International Journal of Innovations \& Advancement in Computer Science(IJIACS), ISSN 2347- 8616 Volume 6, Issue 12, Dec2017, pp.233-236.

[8] Chandra Sekharaiah K., "Impact of the RTI Act within a Public Authority Organization towards Employee Employer Engagement: A Case Study", in Procds. of International Conference 2015, "Enriching Employee Engagement in Organization Role of Psychology", 30Jan-1Feb. 2015, Chennai, Tamil Nadu, India.

[9] Ravi Kumar, Gouri Shankar, K.Chandra Sekharaiah, "CybercrimesTrends and Challenges in Achieving Swachch Digital India: a Case Study", Presented in National Seminar on Concept, Measurement and Enhancement of QoL @ Jnana Prabodhini's Institute of Psychology(JPIP), Pune, Maharashtra, 17-18Nov2017. 
[10] K.Madan Mohan, K.Chandra Sekharaiah, P.Premchand, "A Case Study of ICT Solutions against ICT Abuse: An RTI Act 2005 Success Story", Presented in @ Institution of Engineers(I), Khairatabad, Hyderabad \& published in International Journal of Engineering Technology Science and Research(IJETSR), ISSN 2394 - 3386, Vol. 4, Issue 11, Nov. 2017.

[11] Ramesh Babu J., A.Radha Krishna, K.Madan Mohan, K.Chandra Sekharaiah, "Adaptive Management of Cybercriminal, Maladaptive Organizations, in the Offing, that Imperil the Nation", in Procds. 27th Annual Conference of National Academy of Psychology (NAoP)@IIT, Kharagpur, Theme:Psychology of Millennials, 22$24 \mathrm{Dec} 2017$.

[12] Ramesh Babu J., K.Chandra Sekharaiah, "Adaptive Management of Cybercriminal, Maladaptive Organizations, in the Offing, that Imperil the Nation", Presented in 2nd International Conference on Data Management, Analytics \& Innovation (ICDMAI2018)@Pune 19. 21Jan2018,(Presented).

[13] B.Tirupathi Kumar, K.Chandra Sekharaiah, D.Suresh Babu, "Towards National Integration by Analyzing the Web Mining Results of a Case of Cybercrime" in Procds. of ACM 2nd International Conference on Information and Communication Technology for Competitive Strategies (ICTCS-2016), Udaipur, Rajasthan, India, March 4 5, 2016, ACM - ICPS Volume ISBN No 978-1-4503-3962-9

[14] P.Usha Gayatri and K.Chandra Sekharaiah, "Reviewing a Judicial Case Study of Multiple Cybercrimes", in Procds. of National Conference in Osmania Univ. Law Department, 2016 \& presented in IndiaCOM 2016 International Conf., BVICAM, New Delhi, March 2016.

[15] M. Gouri Shankar, P. Usha Gayatri, S. Niraja, K. Chandra Sekharaiah, "Dealing with Indian Jurisprudence by Analyzing the Web Mining Results of a Case of Cybercrimes", in Springer Procds. of International Conference on Communication and Networks(ComNet 2016), Ahmedabad, India, 20-21 Feb. 2016, pp 655-665.

[16] N. Srihari Rao, K. ChandraSekharaiah \& A. Ananda Rao, “An Approach to distinguish the conditions of Flash Crowd versus DDoS Attacks and to Remedy a Cyber Crime" in Procds. of National Conference on Role of Law Enforcement Authorities and Government in Upholding Justice, SOL,Pondicherry, India , 2-3 Mar. 2018, pp 146. (Presented)

[17] N. Srihari Rao, K. ChandraSekharaiah \& A. Ananda Rao,“An Approach to distinguish the conditions of Flash Crowd versus DDoS Attacks and to Remedy a Cyber Crime" in International Journal of Computer Engineering and Technology, 9(2), 2018, pp. 110-123.

[18] S.Ravi Kumar,K. Chandra Sekharaih, K. Sundara Krishna, "Cybercrimes- Trends and Challenges in Achieving Swachch Digital India Using a Public Cloud: A Case Study" in Procds. of National Conference on Role of Law Enforcement Authorities and Government in Upholding Justice, SOL,Pondicherry, India , 2-3 Mar. 2018, pp 149. (Presented)

[19] P.Usha Gayatri, K.Chandra Sekharaiah \& P.Premchand, "Analytics of a Judicial Case Study of Multiple Cybercrimes against the Union of India" in Procds. of National Conference on Role of Law Enforcement Authorities and Government in Upholding Justice, SOL,Pondicherry, India , 2-3 Mar. 2018, pp 151. (Presented).

[20] N.Santhoshi,Dr.Chandrasekharaiah K,K Madan Mohan, Nagalaxmi, "ICT Based Social Policy for Swatchh Digital India", in Procds. of National Conference on Role of Law Enforcement Authorities and Government in Upholding Justice, SOL,Pondicherry, India , 2-3 Mar. 2018, pp 151-152. (Presented)

[21] K. Madan Mohan, K.Chandra Sekharaiah \& P. Premchand, "Impact of the RTI Act within a Public Authority Organization Towards Employee-Employer Engagement: A Case Study" in Procds. of National Conference on Role of Law Enforcement Authorities and Government in Upholding Justice, SOL, Pondicherry, India , 2-3 Mar. 2018, pp 152. (Presented).

[22] S.Ravi Kumar,K. Chandra Sekharaih , K. Sundara Krishna, "Cybercrimes- Trends and Challenges in Achieving Swachch Digital India Using a Public Cloud: A Case Study" in Procds. of Intnl. Conf. on Science and Technology @ MRIT,Telangana, India,19 - 20 Jan. 2018. (Presented).

[23] Ramesh Babu J., K.Chandra Sekharaiah, “Adaptive Management of Cybercriminal, Maladaptive Organizations, in the Offing, that Imperil the Nation", CSI JC Special Issue, ICDMAI, Pune, 19-21 January 2018, April, 2018. (Accepted).

[24] N. Santhoshi, K. Chandra Sekharaiah, K. Madan Mohan, S. Ravi Kumar, B. Malathi, "Cyber intelligence Alternatives to Offset Online Sedition by in-Website Image Analysis through WebCrawler Cyber Forensics", in Procds. of International Conference on Soft Computing \& Signal Processing (ICSCSP 2018), June 22-23, 2018.
[25] K. Madan Mohan, K.Chandra Sekharaiah, N.Santhoshi, "ICT Approach to Defuse the Cybercriminal Sedition Dimension of Telangana Movement", Accepted for presentation in International Conference on Research Advancements in Applied Engineering Sciences, Computer and Communication Technologies (ICRAAESCCT 2018) on 12th \& 13th July, 2018, BVRIT, Narsapur.

[26] K. Madan Mohan, K.Chandra Sekharaiah, N.Santhoshi, "ICT Approach to Defuse the Cybercriminal Sedition Dimension of Telangana Movement", Accepted for publication in International Journal of Pure and Applied Mathematics (IJPAM), E-ISSN: 1314-3395, ISSN: 1311-8080. (SCOPUS Indexed Journal).

[27] K.P. Singh, "Hostile Witness: Legal and Judicial Contours in Indian Laws", the Haryana Police Journal, October 2017, Volume 1, No. 1, pp. 26-36.

[28] https://sites.google.com/site/sekharaiahk/apeoples-governance forum webpage.

[29] https://www.facebook.com/mahathma.pw.9.

[30] https://twitter.com/PMahathma 